\title{
Analysis of the Relationship Between the Working Environment and Employee Performance in Selected Construction Firms in Karachi City
}

\author{
Muhammad Tarique, LAKHIAR \\ Faculty of Civil Engineering and Built Environment, UTHM, Parit Raja, Johor, Malaysia \\ hf190023@siswa.uthm.edu.my \\ Abd Halid, ABDULLAH \\ Faculty of Civil Engineering and Built Environment, UTHM, Parit Raja, Johor, Malaysia \\ hf190023@siswa.uthm.edu.my \\ Muhammad Tahir, LAKHIAR \\ Department of Civil Engineering, Monash University, Subang Jaya, Selangor Malaysia \\ hf190023@siswa.uthm.edu.my
}

\begin{abstract}
A healthy working environment is important for the performance of workers to prevent undue burden on employees, thus impacting their job efficiency. Numerous working environment factors contributed to job satisfaction. The goal of this analysis was, therefore, to explore the correlation between working environment and the employee performance on the basis of five working environment dimensions. This study utilized the quantitative approach and collected data through questionnaires. The respondents of this study were employees of all positions, which include the manager, senior to junior executives in selected construction firms of Karachi city. By using Pearson's Correlation Analysis, the data were analyzed to measure the relationship among variables. The results indicate that the workplace environment and employee performance have a significant relationship. The support of supervisors was thus identified as the main element in maintaining a positive workplace environment.
\end{abstract}

\section{Keywords}

Workplace environment; Job efficiency; Construction firm; Employee productivity;.

\section{Introduction}

In Employees' performance declines because they have a low view of job security and safety. In return, their behaviours shift by disobeying the laws that lead to a rise in injuries on the jobsite. Various factors impacting employee performance are working hours, colleagues relationship, job safety and security, and the importance required. Athirah Saidi et al. (2019) Job safety and security amongst the most critical considerations for working environment, must be strictly applied at the workplace in order to create a secure and versatile work environment for workers. As Jain \& Kaur (2014) further demonstrated, physical, social and mental working environments are three components of the working environment. The efficiency of an entire company concerned with the welfare of its employees. The company would have a better working atmosphere for its workers so that their tasks could be focused and more productive. The performance of workers may be influenced by the physical working environment, that involves lighting, office layout, temperature, fresh air and noise. Each of these disturbances among employees can trigger health problems, leading to a decrease in the performance of employees. Temessek (2009) Showed that the functional design and decoration of a working environment have eventually been instrumental in improving the employee experience and improving performance. Haynes (2008) discovered that a physical work environment is incorporated into a tangible component which determines employees' ability to attach with work roles and how the quality of their working environment affects their behaviour and their mental, physical and emotional conditions. Earlier studies have said the physical working environment has helped determine employees ' skills and how they deal with their work and affect their behaviour. A study showed that a favourable physical environment could reduce absenteeism and improve staff performance. Therefore the company had to improve the physical working environment in order to retain its employee performance. Charles, Magee, Clarke, Barry, McCarthy, \& Selikowitz (2005) showed that an adequate temperature in the workplace energizes the workforce 
to work at its best, this meant that organization, following nature and demands for the jobs, needed to improve its physical working environment. In their survey, Awan \& Tahir (2015) discovered that relationships with co-workers are at the same hierarchical level and have no authority over each other. It was said that a good connection with teammates must be developed in order to build a conducive working environment. They evaluated their findings, and it was seen that the interaction with the co-worker had a strong positive impact on the performance of the workers. Co-worker interactions and support for teammates inspire workers to carry out tasks even while not included in the employment contract, they feel secure with them. Oswald (2012) stated that the support of supervisors is essential for workers to carry out their tasks. Supervisor support for workers would allow them to do well in their current position and help them further improve their future careers. A competitive and professional supervisor will assists workers in their jobs and encourages them to further establishing significant roles. Pailhé \& Solaz (2008) revealed that physical, biological, chemical hazards in the workplace, communication networks, operating hours, staff empowerment and work speed are essential elements to determining the organization's working environment. Working hours have a relation with practices, programs and policies and initiated by workers for arranging working hours and modifying working time in order to meet their interests.

\section{Problem Statement}

Employee performance can be seen as a backbone organization as it ultimately contributes to its growth. Regrettably, most of the working environment of the company or association, was perceived as unhealthy and unsafe. Borman (2004) said the factors of the workplace environment influence employee performance. Athirah Saidi et al. (2019) said that far more emphasis must be on given to recognition and the control of the work environment as employees often suffer from persistent stress because workers have an adverse view of their environment. The workplace environment often involves laws, regulations, culture, resources, working relationships, place of jobs, interior and exterior environmental factors, all of which affect the way workers conduct their job responsibilities. Past research saw one direct association with a general component that impacted job satisfaction such as pay and promotion, psychological empowerment, remuneration, healthcare services, work pressures and working conditions. Opperman (2016) said that the work environment refers to procedures, methods, frameworks, resources which have a favourable or unfavourable effect on the productivity of individuals.

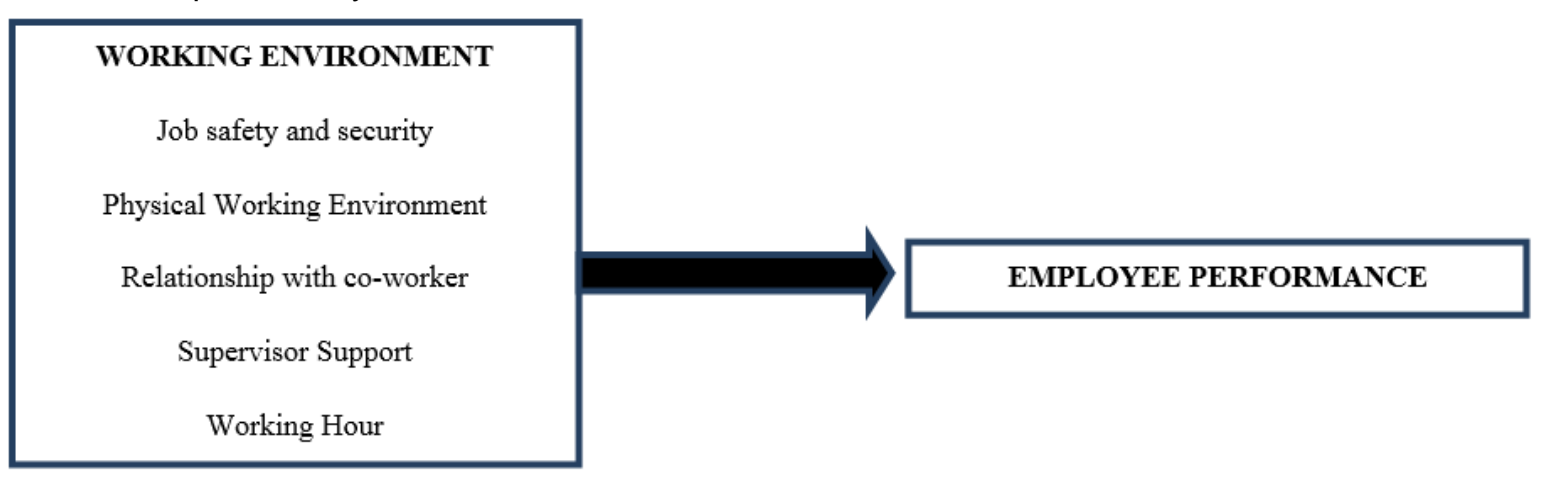

Figure 1 : Research Framework

Employee performance in the company is an important part of maximizing the productivity of the company. Borman (2004) found out that the factors of the work environment at workplace have an immense impact on the performance of workers. Unfortunately, most of the company or organisation considered their working environment to be unhealthy and unsafe. Therefore, in order to analyse and learn more about the employees performance, it is important to evaluate the direct connection between the factors of the working environment and the employee performance with a few components of the working environment, such as working hours, job security and safety, support for supervisors, co-worker relationships and the physical working environment.

\section{Research Objectives}

1. To investigate the correlation between job safety and security and employee performance;

2. To investigate the correlation between physical working environment and employee performance

3. To investigate the correlation between supervisor support and employee performance 
4. To investigate the correlation between co-worker and employee performance

5. To investigate the correlation between working hour and employee performance

\section{Methodology}

In this study, quantitative analysis is performed using correlation analysis in order to test the research hypotheses. Questionnaires on a working environment and employee satisfaction from Borman (2004) were adopted. The questionnaire consists of 8 sections and a total of 42 elements. however, more than 1100 construction companies from the Karachi are registered in various categories with the Pakistan Engineering Council (PEC). This figure was used as the size of the population. This number was used as the population size. Based on Ariani (2015) Table, 291 questionnaires were distributed. Whereas this study utilized web-based survey tool "Google Form" for data collection. One hundred and fifty seven responded to the questionnaire through the web. Therefore, about 15 PEC registered construction companies operating in Karachi participate in this survey.

The reliability test, however, was carried out and the value of Cronbach alpha 0.812 was found to be considered acceptable. In the IBM Statistical Package for Social Science (SPSS) version 26.0 the data obtained were examined in order to explore the relation between variables by the Pearson Correlation Analysis.

Table 1: Background of respondents

\begin{tabular}{ccc}
\hline Characteristics & Sub-profile & Percentage (\%) \\
\hline Gender & Male & $100 \%$ \\
& Female & $0 \%$ \\
Age & $18-25$ years & $31.21 \%$ \\
& $26-35$ years & $36.30 \%$ \\
& $36-45$ years & $22.92 \%$ \\
& 46 years and above & $9.55 \%$ \\
Qualification & Diploma & $23.56 \%$ \\
& Graduate & $62.42 \%$ \\
& Master & $5.73 \%$ \\
Total Years of & Doctorate & $0 \%$ \\
Experience & Others & $8.28 \%$ \\
& 0-5 years & $13.66 \%$ \\
& 6-15 years & $62.02 \%$ \\
& 15 years+ & $24.32 \%$ \\
\hline
\end{tabular}

\begin{tabular}{lll}
\hline PEC category & Financial limit of each category & $\begin{array}{l}\text { No. of } \\
\text { companies }\end{array}$ \\
\hline C-A & No financial limit & 0 \\
\hline C-B & 2,000 Million & 1 \\
\hline C-1 & 1,000 Million & 3 \\
\hline C-2 & 500 Million & 2 \\
\hline C-3 & 250 Million & 4 \\
\hline C-4 & 100 Million & 5 \\
\hline C-5 & 30 Million & - \\
\hline C-6 & 15 Million & - \\
\hline Total & & 15 \\
\hline
\end{tabular}

Figure 2 : The size of firms depends on categories of PEC 
Table 2: Summary of hypothesis testing

$\begin{array}{lccc}\text { Hypothesis } & \text { p value } r \text { value } & \begin{array}{c}\text { Relationship } \\ \text { strength }\end{array}\end{array}$

\begin{tabular}{lccc} 
Ha 1: Physical working environment has a significant & 0.000 & 0.481 & Weak \\
$\begin{array}{l}\text { correlation with employee performance } \\
\text { Ha 2: Supervisor support has a significant correlation with } \\
\text { employee performance }\end{array}$ & 0.000 & 0.521 & Strong \\
$\begin{array}{l}\text { Ha 3: Co-worker has a significant correlation with employee } \\
\text { performance }\end{array}$ & 0.000 & -0.436 & Weak \\
$\begin{array}{l}\text { Ha 4: Job safety and security has a significant correlation with } \\
\text { employee performance }\end{array}$ & 0.000 & 0.337 & Weak \\
$\begin{array}{l}\text { Ha 5: Working hour has a significant correlation with employee } \\
\text { performance }\end{array}$ & 0.000 & 0.368 & Weak \\
\hline
\end{tabular}

\section{Results and Discussion}

The demographic background of the participants was tabulated in Table 1. Consequently, table 3 shows the results of the study that the working environment and the employee performance are significantly related. The above results demonstrated that the dependent variable (employees' performance) is significantly related to all independent variables such as the supervisor support, physical working environment, job safety and security, co-worker relationship and working hour.

According to Ha1, the findings show $r=0.481$ and $p=0.000(p<0.05)$ demonstrating that there is a significant correlation between the physical working environment and the employee performance. This finding is confirmed by Naharuddin \& Sadegi (2013), who have found evidence of disruptions (e.g. noise and improper office layouts) that created discomfort among workers and adversely influenced employee performance.

Second, Ha2 is accepted as the relationship between supervisors' support and employee performance found strongly significant positive, $r=0.521$ and $p=0.000 \quad(p<0.05)$. Razak, Jaafar, Abdullah, \& Muhammad (2008) concluded that respect for managers was the secret to promoting good relations and increasing the degree of self-confidence that would improve employee performance in return.

Based on $\mathrm{Ha} 3$, it has been observed that there is a relationship between the co-worker relationship and the success of workers, $r=-0.436$ and $p=0.000(p<0.05)$. As a result, the hypothesis is accepted. The co-worker relationship plays a crucial role in improving the performance of workers. This is because workers wanted more motivation to carry out their duties and to be completely committed to the organisations. Workers who have perceived a successful partnership with other colleagues in the company would feel responsible and obligated to reciprocate a strong relationship to help them accomplish their targets (Ariani, 2015).

The results have suggested that $\mathrm{Ha} 4$ was not dismissed when it was observed that there is a significant relationship between job safety and security and employee performance with $r=0.337$ and $p=0.000(p<0.05)$. Job safety and security has a major role to effect on employees performance, as job safety and security would guarantee the efficiency of the work of employees. It can improve their incentive to select the best organisations to work with (Allaire et al., 2013). Job safety and security guarantees workers with their bonuses, salaries and benefits, safety at work and career growth, and thus, if companies have poor job security and job stability for staff they would not complete their job and operate properly, leading to lower performance of employees (Mun, Ying, Lew, Wei, \& Ning, 2017).

Ha5 analysed the relationship between working hours and employee performance. It indicates that there is a significant relationship between working hours and employee performance $r=0.368$ and $\mathrm{p}=0.000 \quad(\mathrm{p}<0.050)$. The working hours is weakly correlated with employee performance, as employees are happier and would feel comfortable if companies allow flexibility in scheduling work time and changing work hours. Staff assumed that flexible working hours would improve efficiency because of flexible operating hours. They will work at all hours until the eight-hour duration of work is done within one day (Henly \& Lambert, 2014).

Based on the results, the working environment is also seen as critical in maintaining employee productivity, so supervisors in organization should involve their workers more and more in job preparation and decision-making and display empathy for their employees. 


\section{Conclusion}

In short, a direct link exists between physical working environment, relationship with coworker, job safety and security, working hour, and supervisor support with employee performance. Consequently, Supervisor Support has the great effect on employee performance.

\section{References}

Allaire, J. C., McLaughlin, A. C., Trujillo, A., Whitlock, L. A., LaPorte, L., \& Gandy, M. (2013). Successful aging through digital games: Socioemotional differences between older adult gamers and Non-gamers. Computers in Human Behavior, 29(4), 1302-1306. https://doi.org/10.1016/j.chb.2013.01.014

Ariani, D. W. (2015). Employee Satisfaction and Service Quality: Is There Relations? International Journal of Business Research and Management (IJBRM), 6(3), 33-44.

Athirah Saidi, N. S., Michael, F. L., Sumilan, H., Omar Lim, S. L., Jonathan, V., Hamidi, H., \& Abg Ahmad, A. I. (2019). The Relationship Between Working Environment and Employee Performance. Journal of Cognitive Sciences and Human Development, 5(2), 14-22. https://doi.org/10.33736/jcshd.1916.2019

Awan, .Abdul Ghafoor, \& Tahir, M. T. (2015). Impact of working environment on employee's productivity: A case study of Banks and Insurance Companies in Pakistan. European Journal of Business and Management, 7(1), 329-346.

Borman, W. C. (2004). The Concept of Organizational Citizenship. Current Directions in Psychological Science, 13(6), 238-241. https://doi.org/10.1111/j.0963-7214.2004.00316.x

Haynes, B. P. (2008, July). The impact of office layout on productivity. Journal of Facilities Management, Vol. 6, pp. 189-201. https://doi.org/10.1108/14725960810885961

Henly, J. R., \& Lambert, S. J. (2014). Unpredictable Work Timing in Retail Jobs. ILR Review, 67(3), 986-1016. https://doi.org/10.1177/0019793914537458

Jain, R., \& Kaur, S. (2014). Impact Of Work Environment On Job Satisfaction. International Journal of Scientific and Research Publications, 4(1), 1-8.

Magee, C., Clarke, A., Barry, R., McCarthy, R., \& Selikowitz, M. (2005). An examination of the clinical utility of EEG power measures to identify children with AD/HD. Australian Journal of Psychology, $57,30-30$.

Mun, C. S., Ying, C. T. H., Lew, S., Wei, T. X., \& Ning, T. Y. (2017). The Relationship between Work Environment and Job Satisfaction in Hotel Industry. UNIVERSITI TUNKU ABDUL RAHMAN.

Naharuddin, N., \& Sadegi, M. (2013). Factors of Workplace Environment that Affect Employees Performance: A Case Study of Miyazu Malaysia. International Journal of Independent Research and Studies, 2(2), 66-78.

Opperman, C. S. (2016). Tropical business issues.

Oswald, A. (2012). The Effect Of Working Environment On Workersperformance: The Case Of Reproductive And Childhealth Care Providers In Tarime District. Muhimbili University of Health and Allied Sciences.

Pailhé, A., \& Solaz, A. (2008). Time with Children: Do Fathers and Mothers Replace Each Other When One Parent is Unemployed? European Journal of Population / Revue Européenne de Démographie, 24(2), 211-236. https://doi.org/10.1007/s10680-007-9143-5

Razak, A. A., Jaafar, M., Abdullah, S., \& Muhammad, S. (2008). Work Environment Factors And Job Performance: The Construction Project Manager's Perspective. Retrieved from Quantity Surveying Programme School of Housing, Building and Planning Universiti Sains Malaysia, Penang, Malaysia website: http://eprints.usm.my/16071/1/Arman_Abdul_Razak.pdf

Temessek, M. (2009). Expanding the psychosocial work environment: workplace norms and 34 workfamily. Conflict as Correlates of Stress and Health, 3(171-88). 